\title{
Making Heritage Legible: Who Owns Traditional Medical Knowledge?
}

\section{Sita Reddy*}

\begin{abstract}
In recent years an increasing number of state-based heritage protection schemes have asserted ownership over traditional medical knowledge (TMK) through various forms of cultural documentation such as archives, databases, texts, and inventories. Drawing on a close reading of cultural disputes over a single system of TMK-the classical South Asian medical tradition of Ayurveda-the paper traces some of the problems, ambiguities, and paradoxes of making heritage legible. The focus is on three recent state practices by the Indian government to protect Ayurvedic knowledge, each revolving around the production of a different cultural object: the translation of a seventeenth-century Dutch botanical text; the creation of an electronic database known as the Traditional Knowledge Digital Library (TKDL); and the discovery of an Ayurvedic drug as part of a bioprospecting benefit-sharing scheme. Examined together, they demonstrate that neither TMK, nor Ayurveda, nor even the process of cultural documentation can be treated as monoliths in heritage practice. They also reveal some complexities of heritage protection on the ground and the unintended consequences that policy imperatives and legibility set into motion. As the paper shows, state-based heritage protection schemes inspire surprising counterresponses by indigenous groups that challenge important assumptions about the ownership of TMK, such as locality, community, commensurability, and representation.
\end{abstract}

If recent years have seen the rise in heritage advocacy and assertions of ownership over all forms of knowledge, nowhere is this more evident, or cacophonous, than in the realm of TMK. From bioprospecting for natural drugs to patents on tradi-

\footnotetext{
${ }^{*}$ Center for Folklife and Cultural Heritage, Smithsonian Institution. Email: reddys@si.edu, sitareddy@mac.com

ACKNOWLEDGEMENTS: My grateful thanks first to Vijayendra Rao and Gayatri Reddy for invaluable discussion and intellectual support; Debra Diamond, Jane Anderson, Lalitha Gopalan, Michael Sappol, Alexander Bauer, and two anonymous referees for extremely useful interdisciplinary insights; and to the Rockefeller Foundation and the Smithsonian's Center of Folklife and Cultural Heritage, particularly Richard Kurin, Carla Borden, James Early, and Peter Seitel, for the ideal fellowship and venue to get this paper written.
} 
tional remedies, efforts to propertize ethnomedicine have taken the forefront among heritage initiatives worldwide. Indigenous activists and state actors now routinely make cultural claims to possess or repossess medical and botanical knowledge, while global anxiety over cultural appropriation in this field is so widespread that it even has a name: biopiracy. And yet TMK remains one of the most difficult categories to regulate within the intangible cultural heritage discourse. As a concept that straddles bioresources and folkloristic healing, trade discussions and biodiversity conservation, botanical knowledge and indigenous rights, TMK must respond to diverse legal instruments and ethical codes and thus often falls between the cracks in policy and practice.

This paper describes the ambiguities, problems, and unintended consequences in the process of making medical heritage legible. I rely here on James Scott's theoretical framework of state practices in Seeing Like a State, which outlines legibility"efforts to settle mobile subjects and to simplify complex knowledge"-as the central and perennial problem of statecraft, particularly in the organization of the natural world. ${ }^{1}$ Following recent United Nations (UN) legal conventions that redefine medical heritage as a form of collective property belonging not to a global commons but to nation-states ${ }^{2}$, or as a form of intangible cultural heritage that must be documented before it can be protected, ${ }^{3}$ state-based heritage protection schemes focused on medical knowledge often begin with cultural documentation: namely, the attempt to publicize and codify traditional knowledge, pharmacopeia, and healing practices, through inventories, databases, texts, and archives in order to claim ownership over them. ${ }^{4}$

As Michael Brown and other anthropologists have noted, however, the very process of making knowledge legible contains inherent paradoxes. Redefining TMK as a proprietary resource often ends up removing it from the public domain in an attempt to return it to its alleged creators. This process relies on globalizing Information Society models to make TMK public, but in effect protects it from globalization or at least from the cultural and information flows that result from globalization. ${ }^{5}$ Databases of traditional knowledge, such as India's TKDL, are particularly instructive examples of this paradox. Created to fend off foreign patents on what they define as a nation's heritage, they bear the simultaneous burden of proving that a proposed innovation has been part of the public domain for centuries, but do so by asserting ownership over it, which directly conflicts with their appeals to a universal public domain. ${ }^{6}$ Medical heritage schemes may rely on a premise of cosmopolitan ownership, the claim that heritage belongs to the world; but as Marilyn Strathern notes, they often work in practice to reinscribe cultural boundaries, and to "re-embed or recontextualize indigenous ownership in traditional knowledge."

A second paradox of legibility has to do with what legal scholars call the hyperownership of an increasingly contested biological commons: a situation in which state-based systems of ownership push the boundaries of sovereignty so far in unleashing a spiral of enclosures that they risk creating new property claims, new subjects, and the possibility of an anticommons. ${ }^{8}$ Making heritage legible can cut 
both ways. Although the underlying bureaucratic impulse of state-based cultural documentation is to manage and regulate disordered things (culture) as well as people (subjects), it also simultaneously produces new cultural objects that transform the nature of knowledge, and new cultural subjects—or "biological citizens" who transform the politics of knowledge through contested claims of ownership. ${ }^{9}$ These heritage practices also provide a valuable but underused research archive to explore how norms and normalization inform the exercise of power, particularly for those at the margins of the state. ${ }^{10}$ Taking power in the Foucauldian sense to mean both sovereign and disciplinary power, the heritage archive can thus be read not just as ideology, or a strategy that becomes available to indigenous groups asserting control over medical heritage, but also as an example of coercive power through which they are constructed as incomplete subjects not fully integrated into the state. ${ }^{11}$ It is in this double sense that I refer to the legibility of medical heritage: making traditional knowledge legible as an agenda of state control involves the process of writing, codifying, translating, or digitizing a tradition (the making of cultural objects); but it also refers to the making and management, and perhaps erasure, of difficult cultural subjects.

Drawing on a close reading of cultural disputes over a single system of traditional medicine-the South Asian medical tradition of Ayurveda-this paper will illustrate and contextualize these paradoxes of legibility and ownership through a regional lens. The name Ayurveda, which means science of long life in Sanskrit, refers to the complex of humoral diagnostics and healing practices first codified in South Asian classical texts in the sixth century в.с., and later transformed in modern India through a long history of professionalizing reform that was part of the nationalist project of indigenous revival. ${ }^{12}$ As one of the three great scholarly or written medical traditions of the classical world, namely those that rely on textual sources of authority, Ayurveda has lent itself especially well to legitimation strategies (and legibilizing schemes) that revolve around its texts, whether these are the professionalizing revivalist movements of the twentieth century or the more recent heritage disputes of the early twenty-first century. ${ }^{13}$ My empirical foci in this paper are three extraordinary heritage protection schemes launched by the Indian government to protect TMK, all of which revolve Ayurveda and all of which were initiated within the last five years. Each of these three state practices involved different state actors (national, regional, subnational), different forms of intellectual property (copyright, patent, trade-mark), and the production of different cultural objects: the translation of a monumental seventeenthcentury Dutch botanical text (Hortus Indicus Malabaricus [henceforth Hortus Malabaricus]) based on indigenous Ayurvedic knowledge; the creation of a comprehensive national electronic database of TMK that relied heavily on Ayurvedic texts; and the research discovery of the first Ayurvedic drug based on tribal medical knowledge, which then became part of a model bioprospecting benefit-sharing scheme in the World Intellectual Property Organization (WIPO). 
What these three cases immediately reveal is that even within a single medical tradition, issues of heritage protection, law, and knowledge play out in very different ways. In a way these diverse narratives, each of which carries its own power and cultural anxiety, make it difficult to recognize similar threads of argument or points of convergence or even a common point of reference in the intangible heritage discourse. What these narratives share, however, is how they unfold in response to the law. As I will describe, each of these state-sponsored heritage protection schemes in turn inspired indigenous counterclaims of ownership, such as repatriation on grounds of sacrilege or defamation; secrecy on grounds of restricting heritage within particular groups; or even cultural sovereignty over an idea. Thus, if state schemes attempt to assert control over heritage by publicizing Ayurvedic medical knowledge, the indigenous responses seek to remove heritage from the public domain by further privatizing it. And all these circulating heritage claims and counterclaims, individually and together, raise serious questions about the assumptions underlying cultural ownership of traditional knowledge: questions about collective authorship and original attribution; questions about the primal authenticity of traditional, local, or indigenous knowledge; questions about commensurability with other forms of knowledge or Western science; and questions about community representation.

This, then, is what the paper attempts to map: what Michael Brown calls the "Law of Unintended Consequences" with heritage protection, the as yet uncharted territory of contradictory assumptions and outcomes that the international heritage conventions set into motion, and "the fact that there will always be unforeseen effects, both good and bad, when information enters the public domain." ${ }^{14}$ Focusing on a single system of medicine illustrates how matters that seem monolithic can often reveal a surprising complexity, even multiple pluralities, on the ground. Above all, it highlights the difficulties of umbrella heritage protection schemes in heritage policy, whether these are at the national, subnational, or international levels. One size may not fit all even within the confines of a single system of TMK.

A second goal of the paper is to map medical globalization from the ground up, to locate the contested politics of Ayurvedic knowledge against current understandings of medical exchange that underlie various international UN conventions and national policy documents. At one level viewing the Ayurvedic heritage narratives collectively is thus a useful metaphoric exercise. The progressive complexity of cultural disputes over TMK allows us to trace chronologically, within the context of a single region, the shifting rhetoric underlying intangible heritage discourse over time: for example, the rapid escalation of moral panic around the cultural appropriation of Ayurvedic knowledge from biocolonialism to medical revivalism to bioprospecting and back again. ${ }^{15}$ But at another level, these narratives also point to rifts and ruptures in the heritage discourse that open up into new spaces and new metanarratives that challenge typical understandings of medical globalization, ownership, and heritage protection. 
Ironically, as scholars have begun to note, the methods, language and strategies used in many of these heritage protection schemes draw directly from the globalizing Information Society practices that they are supposed to counter. ${ }^{16}$ And this is where the notion of legibility becomes even more salient. Cultural documentation - whether it is the translation of a text, the creation of a database, or the attribution of collective authorship in drug discovery-makes the assumption that intangible heritage can be isolated, objectified, and then managed through modern management techniques. As all my case studies illustrate, making Ayurvedic heritage legible involves a shift from safeguarding traditional knowledge to the documentation of that knowledge as information, a trend noted by other observers of heritage protection schemes worldwide. ${ }^{17}$ And it is here at the heart of the process of cultural documentation, of producing medical information, that we see most clearly the ambiguities of protecting TMK. Protecting traditional knowledge as information involves locating it somewhere on a continuum between "wisdom" and "data," a process that transforms the very nature of these cultural objects in question. ${ }^{18}$ In the case of TMK, pharmaceuticals, medical industries, and now even sovereign nations have moved from collecting whole specimens to banking them in the form of information-what Bronwyn Parry calls "derivatives" - within registries, databases, and inventories. ${ }^{19}$ The discourse has moved, in other words, from medical heritage as geographical antiquity to medical heritage as plant extracts.

By entering the realm of information, medical heritage also opens itself to information's unique properties, such as its essential homelessness or the fact that it can simultaneously reside in several places, and thus to increasing claims and counterclaims of ownership. Indeed, disputes over information, when compared to territory or tangible property, can be endlessly and exponentially contested. Protecting TMK as bankable information thus unleashes infinite new possibilities for ownership, new forms of entitlement, and strategies of management. To quote Marilyn Strathern,

At no other moment in history have we seen the world shrinking in terms of actual resources, and yet expanding in terms of new candidates for ownership. New kinds of entities are being created and new claims for property made ... and never more so than in the world of biological knowledge or resources. ${ }^{20}$

It is against this general background on cultural ownership that I position my paper.

\section{REORIENTING AYURVEDA}

At the outset, even before I begin describing the details of ownership disputes over Ayurvedic knowledge, I should acknowledge that this is a topic that has come back to haunt me. My 2000 dissertation on the revival of Ayurveda in America had a short epilogue on the future of ethnomedicine in a globalizing world, which 
focused on emerging market trends such as Ayurvedic tourism and the sale of proprietary Ayurvedic medications worldwide. ${ }^{21}$ My argument then was that ethnomedical tourism or the selling of place-based heritage to global audiences prefigured ways in which local medical practices would be revived in the twenty-first century. The underlying subtext was that the global market would save this tradition from loss, not nationalist revivals of practice or institutionalized reform of Ayurvedic education, which had been judged a professionalizing failure. ${ }^{22}$ The logic of the market, in my view then, would even create new forms of local authenticity. From what I observed, Ayurveda was reinvented for global audiences not just as a transnational medical system but as a transnational cultural form or "ideoscape," an ethnomedical cure for disease as well as modernity, healing the West not just through medical efficacy but through cultural difference. ${ }^{23}$ Here, in other words, was a sort of Orientalism in reverse, a market Occidentalism that encouraged the global circulation of Ayurvedic goods on the premise that this heritage belonged not to India alone but to all humanity: a phenomenon that John Merryman, referring to another context and era had termed "cultural internationalism." ${ }^{24}$

Over the last few years, that prediction proved to be only partially right, and therefore partially wrong. I was wrong on two counts. First, I had not foreseen the considerable role that would be played not by the market but by the state in the production of Ayurvedic heritage. Here, I broadly define state to mean "state practices" in James Scott's sense of the term-as the "technologies of state, knowledge practices and law" that include governance by international, national, or subnational entities but also, conversely, indigenous forms of resistance that speak back to the state in the same idiom. ${ }^{25}$ Scott's thesis about knowledge practices, in particular practical knowledge or metis, describes the perils of a marriage between powerful states and high modernism. When powerful states undertake modernizing projects, their simplification of complex knowledge prepares the way for disasters to unfold. Postcolonial knowledge practices in this sense are similar to what Timothy Mitchell calls "the rule of experts" - the governmentality of heritage that foregrounds ways in which power structures knowledge, in which power produces knowledge through difference, much as colonial knowledge practices and archives once did. ${ }^{26}$

Needless to say, this production of state-based Ayurvedic heritage schemes did not occur in a policy vacuum. In five short years, transformative shifts in indigenous rights movements and sustainable development strategies have managed to change the international heritage policy environment considerably. Recent UN legal instruments and national laws in an increasing number of signatory nations have helped to redefine medical and genetic heritage as cultural property owned by nation-states and local communities. The 2003 Convention to Safeguard the Intangible Cultural Heritage (CSICH) encourages the creation of inventories and databases of TMK by signatory nations. ${ }^{27}$ Ownership and control over TMK and biodiversity have become the new realities and tropes of medical globalization. If anything, the trend now is a move away from cultural internationalism and to- 
ward a more rigid cultural nationalism, even "cultural intra-nationalism," to use Joe Watkins' term-a move that parallels what legal scholars call the new enclosures movement in ownership of the global commons. ${ }^{28}$ States and communities are stronger players than ever before in successful ownership disputes over TMK.

That brings me to the second blind spot in my earlier work on Ayurveda. If I did not foresee the role of state-based systems of ownership since 2000, I completely underestimated how central Ayurveda would become to national heritage protection schemes or indeed to the global heritage discourse. These days cultural disputes waged by the Indian government center not on art, antiquities, and monuments but on ethnobotanical and TMK, whether these are legal disputes over plant and genetic resources or medicinal applications and folkloristic knowledge. ${ }^{29}$ Over the last few years, Ayurvedic healers, indigenous activists, and state advocates have been at the forefront in asserting control over TMK in a variety of international arenas, WTO, WIPO, UNESCO; and in turn, their campaigns have been adopted as prototypes and models of heritage protection by these organizations.

At one level, this prominence of Ayurvedic knowledge in national and global heritage schemes reflects historical shifts in postcolonial revivalist strategies among healers within India. Professionalizing Ayurvedic advocates have moved from nationalist preoccupations with therapeutic practice - and the reform of this practice through educational standards or credentialization that dominated more than half a century's struggle_- to now waging global contests over knowledge itself: the pharmacopeia, texts, the source, origins, taxonomy, and epistemology. ${ }^{30}$ Another reason for the visibility of Ayurveda and TMK in cultural ownership disputes could be that medicine itself is one of the most inclusive categories in the intangible cultural heritage discourse. As a technical system of knowledge that straddles bioresources as well as healing traditions, trade discussions and biodiversity conservation, and intellectual property and indigenous rights, TMK includes ethnobotanical knowledge on plant and genetic resources as well as folkloristic oral traditions that deal with medicinal applications of these resources. Perhaps more than any other intangible cultural form, TMK is at once thing as well as healing practice, cultural object as well as Traditional Cultural Expression-in Walter Benjamin's words both "aura as well as commodity," an all-encompassing category whose words very inclusiveness keeps it firmly in the public eye among cultural ownership disputes. ${ }^{31}$

But above all, disputes over Ayurveda enjoy such attention in the global heritage discourse because of their economic importance and their links with trade, pharmaceuticals, and development. More than other forms of heritage, TMK has enormous global reach in the commercial health arena, with its therapeutic potential for natural drug manufacture. The global market for Ayurvedic proprietary medicines alone is $\$ 150$ million, expected to grow to $\$ 1$ billion by 2008 . This, in other words, is heritage played at extremely high stakes; holders of traditional knowledge in the biodiversity-rich South often stand much to lose, and often do lose, against powerful pharmaceutical corporations in the North. As various 
authors have noted, the increasing redefinition of medical heritage as information also magnifies the role of intellectual property rights (IPRs) in cultural disputes, given that the rise of the Information Age has moved the flash point debates in property from land to information. ${ }^{32}$ Within intellectual property, a new public domain movement even seeks to protect a commons of information against the encroachment of private property. ${ }^{33}$ At a time when ownership over medical information is more commercially valuable than how it is practiced or how it travels, it is not surprising that intellectual property in TMK, and in particular biological patents, have become sources of great wealth and profit.

This is where it becomes necessary to historicize the role of the biological commons and the 1994 Agreement on Trade Related Aspects of Intellectual Property Rights (TRIPS), both of which are critical in global disputes over TMK. In medicine and biotechnology the reliance on the biological commons-which includes medical, natural, and genetic resources-as a resource to be prospected for its commercial potential or as a building block for intellectual property is so routine that it goes by its own name: bioprospecting. ${ }^{34}$ And it is here that the 1994 TRIPS changed everything. As legal scholars Anupam Chander and Madhavi Sunder argue, TRIPS transformed the global biological commons by propertizing the information resources of the West but leaving in the commons the information resources of the Rest, such as genetic resources and traditional knowledge.

Native peoples once stood for the commons ... But in the advent of
an awareness of the valuable genetic and knowledge resources within
native communities and lesser developed nations, the advocates for the
public domain—and, in turn, propertization--have flipped. Now, cor-
porations declare the trees and the shaman's lore to be the public do-
main, while indigenous peoples demand property rights in these
resources.

This increasing propertization of TMK provides precisely the larger context for a detailed examination of the three Ayurvedic heritage schemes with which the paper began.

\section{WHOSE KNOWLEDGE? TEXTS, GARDENS, AND TAXONOMIES}

My first case, the translation of the famous herbal Hortus Malabaricus, reads almost like a parable about biopiracy. The story begins in the late seventeenth century, when Hendrik Adriaan van Rheede, the Dutch commander of Malabar in the service of the Dutch East India Company (VOC) at the time, compiled and published this monumental illustrated botanical text. Begun in 1673 and taking more than a decade to complete, this 12 -volume masterpiece marked a climax in late seventeenthcentury botanical literature as the first definitive history and survey of tropical botany in South Asia. The exquisitely illustrated volumes included wide-ranging information on the medicinal uses of 740 plants, valuable not only because of its 
detailed descriptions of the flora of Malabar that drove commercial trade routes and colonial exploration, but also because of its seminal influence on the scientific development of botany, tropical medicine, and medicinal gardens in cosmopolitan centers of learning like Leiden and Padua. Van Rheede's conceptualization of Malabar as "the garden of the world" persuaded him to make a more fundamental set of associations between landscape and people, and between forests, medicine, and health, all of which were to have a decisive impact on Dutch colonial responses to deforestation. We also know that Hortus Malabaricus was the main source for Carl Linnaeus's knowledge of Asian tropical flora, which in turn critically influenced the development of species taxonomy in his Species Plantarum. ${ }^{36}$

But even more interestingly, the Hortus Malabaricus held tremendous epistemological significance in its reliance on local medical knowledge. Unlike other illustrated herbals compiled at the time, Van Rheede relied almost entirely on indigenous collaborators: three Konkani Brahmin scholars, who provided textual reference, but more importantly, Ayurvedic physicians from the Ezhava or low-caste toddy tappers, who provided the empirical plant knowledge and functional taxonomies of classification (see Figure 1). As historian Richard Grove describes, the main Ezhava informant was the well-known healer, Itty Achudan, who not only shared his community's secret texts but also selected, procured, and classified the plants for inclusion in Hortus Malabaricus. ${ }^{37}$ In privileging the Ezhava, or nonBrahmin view of the world, Van Rheede transformed not only Ayurveda itself (often understood as an orthodox elite Brahminical tradition) but also colonial botany and thus Western science. Ezhava botanical classifications and medicinal garden schemes were recreated intact in Leiden. Indeed, Linnaeus is said to have directly incorporated both the order and the functional taxonomy originally provided by the Ezhavas. But the real irony here is that although Ezhava ethnobotanical information may live on in global science (Itty Achudan was considered so influential that the entire plant genus Achudemia was named after him), the actual role of Ezhava informants has long been forgotten. Local Ayurvedic knowledge may have transformed the origins of medical botany and Western science but has been written out of global history.

Almost 350 years later, Kerala University set out to reverse this extraordinary history with its new English translation of Hortus Malabaricus in 2003. The famous text had defied translation for centuries, and attempts to bring out Dutch and English translations had all failed. Van Rheede's feat was prodigious in that he brought out the 12 finely illustrated volumes in Latin, the accepted language for scientific work in Europe at that time, but he had also employed three other scripts, the local Malayalam, Arabic and Sanskrit, while plant names also appeared in the Portuguese and Flemish languages (see Figure 2). Thus, the multilingual volumes, with their copious introductions, forewords, dedications, references, and certificates given by Van Rheede to the native physicians, all of which contained extensive social and historical information about India, had largely remained off-limits to serious scholars and analysts. 


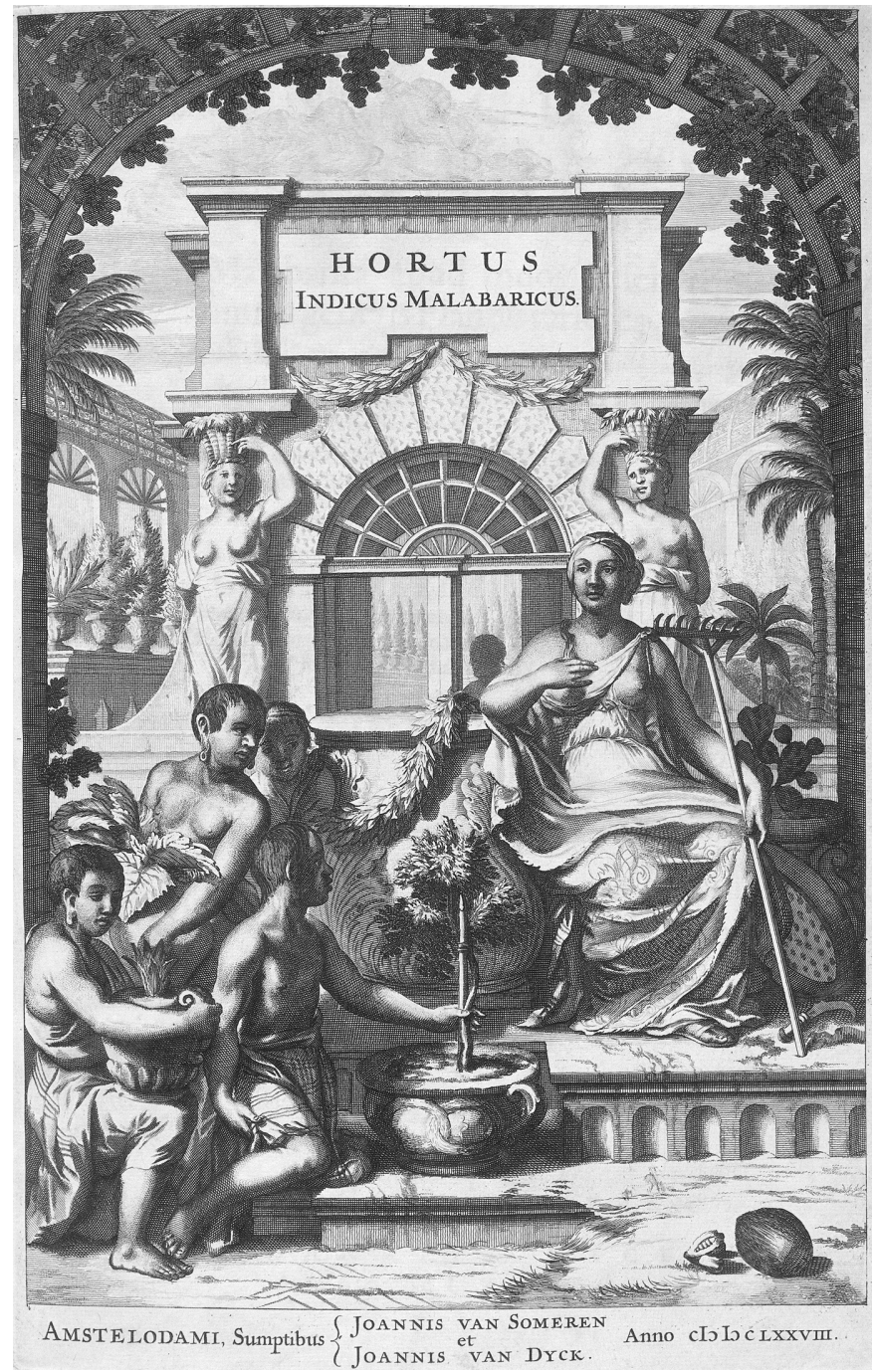

Figure 1. Frontispiece of Hortus Malabaricus vol. 1 (1678). Anonymous etching of the Garden of Malabar in which four kneeling indigenous Malayalee children, identified by their elongated earlobes, offer potted plants to the seated figure of Indian Botany. Courtesy of Wellcome Library, London.

Until October 2003, when Kerala University unveiled the newly translated Hortus Malabaricus volumes, presenting the first set to the president of India as a landmark event. ${ }^{38}$ Professor of Botany, K. S. Manilal, who spearheaded the university's 30-year translation project, argued that the original Hortus Malabaricus represented the earliest example of printing in the Malayalam language. It was the "native heritage" of the people of Kerala, their lost knowledge, a hidden history that the world needed to recognize. In Manilal's view, the ethnomedical information in its volumes was Kerala's cultural heritage but it belonged to all humanity, a for- 


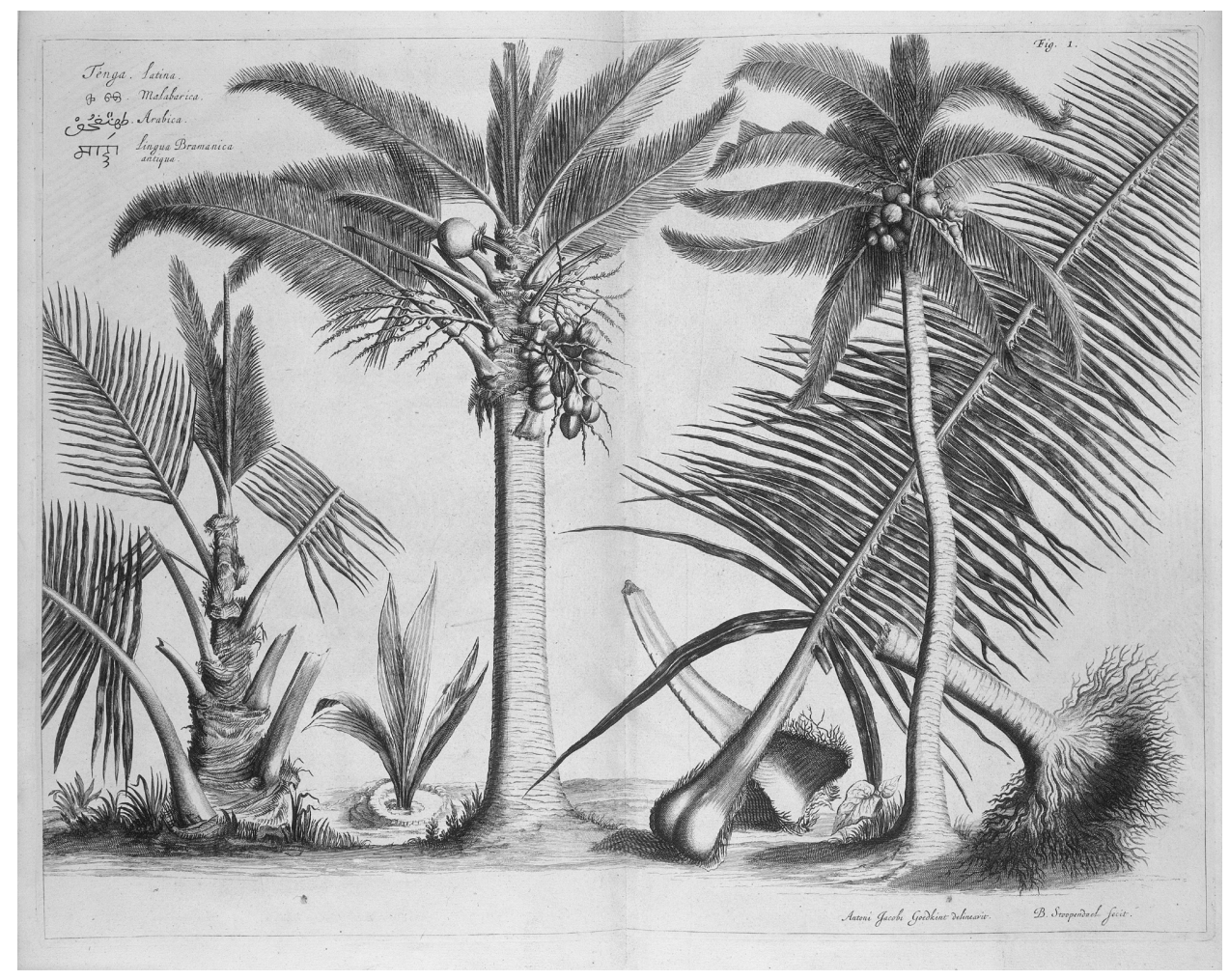

Figure 2. Engraving of Tenga (coconut palm) from Hortus Malabaricus vol. 1 (1678) by Bastiaan Stoopendael after a drawing by Antoni Jacobsz. Includes multi-lingual inscriptions in Latin, Malayalam, Arabic, and Sanskrit. Courtesy of Wellcome Library, London.

mulation similar to one used by cultural internationalists since the Hague Convention. The translation of the volumes thus needed to be widely publicized to highlight the former glory of Kerala and traditional Ayurveda, but it also had to build on the legacy of the Latin Hortus Malabaricus. ${ }^{39}$ This, in other words, is not strictly a claim of ownership but a routine revivalist strategy with a golden age view of history-of recovering precolonial Edenic pasts-except that in this case the tradition to be restored was not classical Brahminism but itself constructed through colonial intervention. Indeed recent accounts go so far as to laud Manilal, himself an Ezhava, as a second Van Rheede. ${ }^{40}$

But beyond epistemology, the Hortus Malabaricus and its English translation hold a new relevance in today's world where natural drugs are gaining fresh recognition but are plagued by biological patent laws and IPRs. Some patent experts think that translating texts like Hortus Malabaricus into English works as a doubleedged sword: It may actually help rather than hinder biopirates and "would hand heritage to them on a platter" especially in the absence of universal acceptance of the Convention Biological Diversity. ${ }^{41}$ Their fear is that the translated Hortus Mal- 
abaricus, now available at US $\$ 900$ for a set, would enable biopirates to apply for patents without even having to travel to India, as did earlier ethnobotanists.

Almost on cue, the digital bioprospecting project at the Mayo Clinic College of Medicine in Rochester, Minnesota, responded to the news of Hortus Malabaricus' English translation with an announcement. ${ }^{42}$ Digital bioprospecting is a hybrid approach to identifying the therapeutic potential of medicinal plants, which lies in between ethnobotany, with its reliance on traditional healers, and modern random high-throughput screening that needs no access to traditional knowledge. It involves the rigorous comparison of ancient herbal texts with modern medical databases to identify promising candidates for further examination and screening. The program's research wing has already analyzed the other major seventeenth-century text on the tropical botany of Asia: the Ambonese Herbal compiled by George Rumphius. Stating that the Hortus Malabaricus was next in line for analysis the researchers stated that working on the translated text would cut down the prospecting time significantly; in this case, they would be able to mine its resources in less than one quarter the time it took for an ethnobotanical expedition.

This is where we must locate the indigenous Ezhava response that arose in May 2004. Spokespersons for the oldest Ezhava association in southern Kerala, the Ezhava Social Reform Movement, a largely subnational caste-based coalition in local Indian politics, used the occasion of their centenary to flood Kerala University with letters arguing that future publication orders for the translated Hortus Malabaricus, which is now available only by special order, be restricted to those placed within state and national borders. Although a weak political group, the movement has managed nonetheless to articulate an argument in terms borrowed right out of the 1993 UN Declaration on Rights of Indigenous Peoples to land, territories, and resources: ${ }^{43}$

It is our right to organize over our own biodiversity, our medical knowledge.... With the biopiracy that has occurred over the centuries, we don't need to repeat the mistakes of history. What he (Itty Achudan) offered the Dutch colonials was knowledge that had been in our community for centuries." 44

Unlike Manilal and Kerala University, who argue that the Hortus Malabaricus relied on unacknowledged native heritage which now deserves public recognition, the Ezhavas suggest that they own the text on the grounds that their ancestors were its original authors. This is what Watkins calls a classic "cultural intranationalist" claim over heritage: a strategic assertion of rights over knowledge that the Ezhavas make as "cultural citizens" (based on caste) that does not disturb the territorial integrity of the nation state. ${ }^{45}$

In the Ezhava view, the appropriate response, now that Hortus Malabaricus has been translated and is in the public domain, is what scholars have called the secrecy approach in heritage protection: an inward protective turn intended to restrict the global circulation of information. Another radical nongovernmental 
organization (NGO) has taken this particular cultural claim even further. They have called for the repatriation of colonial botanical texts like the original Latin Hortus Malabaricus from libraries in the Netherlands, Portugal, and the United Kingdom. This is a bizarre variation on selective Native American Graves Repatriation Act (NAGPRA) policy targeted at libraries, where the preferred strategy chosen by vulnerable groups is the policy of restricting information from archives depending on their perceived utility or sacred and ceremonial content.

Whether or not the Ezhava response grows into a social movement or even a strong political resistance remains to be seen. Meanwhile, the very fact that these heritage claims are made at all is worth noting. If anything, the larger question offered up by this case is the indeterminacy of knowing how to locate or separate local indigenous knowledge in global histories. As the ongoing Hortus Malabaricus dispute so clearly demonstrates, even if we accept that a colonial text or herbal fixes local knowledge at a particular point in space and time, it is not clear at which point they can be (or how they should be) untangled to locate them in heritage policy.

\section{E-TANGIBLE HERITAGE: THE TRADITIONAL MEDICAL DIGITAL KNOWLEDGE DATABASE}

My second case of Ayurvedic knowledge documentation is the very different example of a prior art approach to heritage protection. In 1999 the Indian government fought and won a costly legal battle to revoke a U.S. patent for the medicinal use of turmeric (Curcuma longa) to heal wounds, a therapeutic property that had been well known in India for generations. In asserting this TMK as their heritage, the plaintiff, the Center for Science and Industrial Research (CSIR) on behalf of the state, relied heavily on Ayurvedic texts in the legal brief. Soon after, as part of a four-year struggle known as the Neem Campaign in 2001, a transnational consortium of NGOs successfully revoked a similar patent on the properties of neem (Azadirachta indica) as a fungicide, that had been granted by the European Patent and Trademark Office. In the brief, well-known antiglobalization activist Vandana Shiva stated, “The neem tree is India's sacred goddess ... our sacred heritage. Neem in Sanskrit is referred to as sarva roga nivarini-a term that means cure for all ailments. To take this ancient knowledge from us is blatant and exploitative biopiracy." 46

Largely to prevent future patent appropriations of medicinal heritage, the Indian government launched an exhaustive electronic database of Ayurvedic knowledge, the Traditional Knowledge Digital Library (TKDL). This, as various interlocutors have described, is an example of defensive publishing, a form of negative protection in the law to prevent the inappropriate exploitation of traditional knowledge by the developed world, similar to the American Association for the Advancement of Science's Traditional Ecological Knowledge Prior Art Database 
(TEK-PAD). The creation of the TKDL is also directly inspired by the $2003 \mathrm{CSICH}$, which in Article 12 calls for the preparation of "one or more inventories of the intangible heritage present in [each nation's] territory." ${ }^{7}$

As Chander and Sunder describe, traditional knowledge inventories begin with the premise that one method of avoiding the unequal exploitation of a biological commons is to defeat attempts to propertize it. "Because novelty is one criterion of patentability, the demonstration of prior art (e.g., a published description of the medicinal properties of an herb) should lead to the denial of a requested patent. But in contexts where a patent request deals with information that was already known among indigenous traditional communities, international patent offices often face a practical challenge in assessing novelty." ${ }^{48}$ The argument made by nation-states to create traditional knowledge databases and offer them to patent offices worldwide is a preventive one; by improving the available prior art information, they would prevent commercial exploitation and propertization by pharmaceuticals. The leading players in this effort are, not surprisingly, those nations with written systems of TMK and the most to lose in economic terms: China and India. China's Traditional Chinese Medicine Patents Database is a comprehensive record of traditional acupuncture, herbal medicine and mineral drugs in a format that can be accessed and searched by international patent examiners. But it is the Indian TKDL that is perhaps "the most self-conscious example" of modern twenty-first century archive creation to make traditional knowledge inalienable from the public domain. ${ }^{49}$ In the words of Raghunath Mashelkar at the CSIR who led the effort, "It seeks explicitly to build a bridge between the knowledge contained in an old Sanskrit verse (Shloka) and the computer screen of a patent examiner in Washington." 50

And indeed, the TKDL contains information on 36,000 formulations used in classical Ayurveda. The construction of this database in itself is a fascinating cultural history waiting to be told: Almost 300 Vaidyas, Sanskrit scholars, and analysts were employed for two years to translate verses (Slokas) and aphorisms (Sutras) from the traditional pharmacopeia and Ayurvedic compendia (Samhitas) into structured language using a classification called the Traditional Knowledge Resource Classification; a second group isolated medicinal uses of plants from these to list them in databases; and yet another group of analysts matched these entries with original sources to compare and validate their content. ${ }^{51}$ Here we have information that supposedly reflects a seamless connection between the wisdom of ancient treatises and the data that can be recorded in a database. The question that remains, however, is whether it was really all that seamless.

Within international and Intellectual Property circles, the TKDL is an unprecedented hit. The database set international standards for registries of traditional knowledge, which were adopted by the intergovernmental committee of WIPO in 2003. Presented in English, French, German, Spanish, and Japanese, the information was created in a format accessible by international patent offices, and its classification of bioresources has even been adopted by the International Patent 
Classification (IPC). ${ }^{52}$ The TKDL is, in other words, possibly one of the most important documentations of TMK in the public domain. As one measure of its impact, several developing nations in Asia and Africa are now following the WIPO model to develop the possibility of creating similar databases of medical knowledge. ${ }^{53}$ Meanwhile, in a related effort within India, some regional states have started TMK registries or Community Biodiversity Registers-village or districtlevel participatory initiatives that collect indigenous knowledge through existing local decentralized political structures, and are intended to work in parallel with the national database. ${ }^{54}$

But within Ayurvedic practitioner circles, the technocratic, top-down nature of the electronic database has not escaped criticism. In the first instance, Indian library and technology experts suggest that digital media technologies are far more fragile, prone to degradation, and obsolescence than earlier thought; now they wonder if TKDL funds might have been better focused on the preservation or conservation of the texts themselves. ${ }^{55}$ A more important and far-reaching set of critiques comes from the critical development literature, which argues that this headlong rush toward digitizing knowledge transforms the very nature of medical heritage: specimens are turned into derivatives and practical knowledge is decontextualized, raising serious questions about the commensurability of indigenous knowledge with Western science.

Scholars like Arun Agrawal suggest that there are fundamental epistemological contradictions at the heart of TKDL and, indeed, of indigenous knowledge database creation itself. As an example of ex situ conservation, the instrumental logic of database creation encourages a set of homogenizing processes whereby knowledge is particularized (separated as types and fixed in time), validated (abstracted from context), and generalized (catalogued, archived, and circulated)_processes that strip away all the detailed, contextual aspects that could even potentially mark it as indigenous. Much like Scott's argument about practical knowledge, Agrawal claims that this essentially scientizing process is ultimately untenable; indigenous knowledge can never be thus isolated. When implemented as state practice, indigenous knowledge databases could well be Scott's potential disaster waiting to unfold. More than anything else, they ensure that utility and value become the only operating principles in the archiving of indigenous knowledge-a self-fulfilling circular logic by which only useful or potentially valuable knowledge, however defined, become worthy of protection.

These inherent epistemological tensions within databases are, however, not the only problems that plague the TKDL. The most interesting response and counterclaim has come from the shuddha or pure Ayurvedic practitioners, a subgroup or professionalizing faction among Ayurvedic advocates in postcolonial India who were not consulted during the database creation. Since the 1940s, the politics of professionalizing Ayurveda has been divided into two streams of revivalists: the straights, or the shuddha practitioners, and the integrated practitioners, who believed it was necessary to compete with biomedicine by borrowing its institutional 
practices, each with their own professional associations, schools, and political lobby groups. ${ }^{56}$ Although the shuddhas had several charismatic leaders through the 1950s, they had withered into an insignificant group by the 1980s that had lost the professionalizing high ground and were widely perceived to be the casualties of development and liberalization. ${ }^{57}$ By 2003, policy recommendations had begun to clearly favor integrated Ayurvedic institutions, curricula, standards, and practice, and integrated practitioners dominated the public face of Ayurvedic politics. ${ }^{58}$ Faced with the TKDL, however, some shuddhas seem to have found a new cause around which to mobilize. As Luddites among the Ayurvedic revivalists, they criticize both the technology and the very premise of an authentic Ayurvedic database. Their argument follows a logic commonly known in the heritage literature as the "sacrilege or defamation" grounds for exclusive use. ${ }^{59}$ In their view, sacred Ayurvedic texts should not be defamed by exposing them to secular or public scrutiny; access to these texts should be restricted only to scholarly practitioners who have immersed themselves in this knowledge for decades; and thus they were the rightful interpreters of these sacred objects. Some of these practitioners have already registered a complaint about TKDL (through their professional association) and are ready to contest this "contamination" of Ayurvedic tradition to prevent it from being used in global arenas such as WIPO ${ }^{60}$ One prominent practitioner has even threatened to wage a legal dispute in the Indian courts to reclaim exclusive use over sacred texts by making Ayurveda itself (and its reigning god Dhanavantri) the plaintiff. $^{61}$ This may not be just fanciful or far-fetched: It is possibly a reference to two famous tangible heritage disputes over art antiquities in which two valuable Indian bronze icons were successfully repatriated from international art museums after protracted legal cases that featured the gods themselves as plaintiffs and jurisdictional personalities! ${ }^{62}$

Interestingly, the shuddha practitioners within India may have an unlikely ally abroad, particularly in the United States with its semiprofessional centers of alternative healing where some of them regularly lecture and conduct workshops. Given the particular form that New Age Ayurveda has taken, with its neocolonial nostalgia for an authentic East, it is conceivable that this could eventually lead to an unorthodox heritage coalition-a transnational Ayurvedic advocacy networkthat could mobilize for the first time on behalf of a medical tradition rather than a nation, community, or tribe. ${ }^{63}$

\section{CUI BONO? BIOPROSPECTING WOES}

The third heritage case I describe is a bioprospecting tale gone awry. It deals with the fallout of a state-sponsored, benefit-sharing scheme during the discovery of an Ayurvedic drug that was developed with tribal medical knowledge. The scheme itself should be seen against the 1992 Convention on Biological Diversity (CBD), which took biological heritage out of the global commons and gave it back to 
national jurisdictions. In Articles 8, 15, and 16, the CBD sets forth a multilateral framework for the harnessing of pharmaceutical value of biodiversity; but it also ensures that some benefits of this exploitation come back to source nations and source communities in the South in the form of "equitable returns" and "benefitsharing arrangements" between the providers and users of traditional knowledge. ${ }^{64}$ Benefit sharing with the community, in other words, is a nonmarket tool to compensate knowledge holders that is actively encouraged by the CBD and is most developed in bioprospecting ventures. ${ }^{65}$ India, like all parties to the CBD, is obliged to take legislative and administrative measures toward these goals and provide a broad framework to guide benefit-sharing arrangements for biological resources. The passage of the 2000 Indian Biodiversity Law strictly regulates international access to bioresources for both commercial and research use with heavy fines for breach of violation. Even with this, however, the implementation of the Convention is riddled with problems. Although the CBD recognizes that the authority to determine access to bioresources rests with national governments, it is silent about the ownership or property rights of these resources. It is also silent about what equitable or community really mean on the ground when benefit-sharing schemes are operationalized.

The case I describe here begins in 1988, when the Tropical Botanical Garden and Research Institute (TBGRI), an important government research institute and the largest botanical garden in Asia, held a large ethnobotanical field study in the Agastyar forests of Southwest India. ${ }^{66}$ These forests are home to the Kani, a tribe of approximately 17,000 nomadic traditional collectors of nontimber forest products, who now lead a primarily settled life in tribal hamlets. The Kani use a wild plant for energy that they call arogyapacha, which was identified by TBGRI as Trichopus zeylanicus. Three Kani informants originally divulged this information to TBGRI researchers, who then isolated the active pharmacological elements, developed this restorative herbal medicine applied for two patents, and sold the manufacturing license to a prominent Ayurvedic company in India (the Arya Vaidya Pharmacy) for a fee of Rs. 10 lakhs (approximately \$25,000). Arya Vaidya Pharmacy in turn bought the eight-year license to manufacture and market the new drug Jeevani as an antifatigue sports medicine. By the terms of the benefit-sharing agreement, TBGRI agreed to share $50 \%$ of the license fee and $2 \%$ of the royalty on profits with the Kani community for eight years-all of which, according to the CBD and TBGRI, seemed just and equitable compensation for tribal medical heritage. And indeed, once the drug Jeevani was marketed, the first payment of Rs. $520,000(\$ 12,500)$ was made in 1999 , to be shared by the tribal community and TBGRI. But this marks the point when problems in the arrangement began to emerge.

Because collective ownership or community authorship is often assumed in benefit-sharing agreements, the underlying question in state-sponsored schemes of heritage compensation like this is always: Whose heritage are we compensating? And so the first set of challenges to the Kani benefit-sharing arrangement cen- 
tered on how to define the community. The problems began with the formation of a trust, the Kani Samudaya Kshema Trust, to administer the benefit-sharing process with the help of other NGOs in the area. As Anil Gupta describes in his report, at first there was enormous suspicion about the trust itself (in 1998, for example, it had only 500 members), which resulted in a general refusal by Kani tribals to attend meetings organized by TBGRI. But the main problem may have been handed down by the CBD itself, which lumps together indigenous and local in its definition of community. This case powerfully demonstrates the dangers of assuming that the indigenous Kani communities, and the local political entities, are isomorphous or even share methods of governance. As Gupta and others have shown, TBGRI failed to recognize that traditional political systems among the Kanis have eroded and been replaced by those of nontribal local communities. Rather than governance by a tribal chief (Mootha Kani), India's current administrative system, referred to as the Pancayati Raj, is based on the principle of devolution of administrative powers to the local village level under the Indian Constitution. Unlike the Kani, the pancayat's forms of goverment and decision-making bodies are democratically elected. ${ }^{67}$ A primary source of confusion may have been the fact that the Kanis currently live in three pancayat areas, which lie across state and district borders. Thus when TBGRI interacted primarily with the Kanis from one pancayat area, those who lived in the other two pancayats were offended by what they saw as TBGRI's cultural insensitivity and bias. Several other village-level leaders boycotted the meetings organized by TBGRI to administer the agreement, arguing that the Trust was neither representative nor participatory. Things culminated in September 1995 when a group of nine Kani medicine men or tribal healers, (the Plathis) — who own customary rights to medical knowledge-even wrote to the chief minister of Kerala, who is nominal head of TBGRI, objecting to the sale of their heritage to a private company.

The second set of challenges to the benefit-sharing scheme was even more complicated. It stemmed from the details of the licensing agreement with the drug manufacturer Arya Vaidya Pharmacy; and here the argument was over the procurement of the plant involved (arogyapacha), its sustainability in the tropical forest, and the larger issue of the forest as biological commons. Arogyapacha is a forestfriendly perennial undergrowth that grows under the natural forest canopy; and as part of the arrangement, TBGRI assured the manufacturer of a regular supply of the cultivated raw plant for seven years. But here again the scientists quickly learned that the medicinal qualities of the plant are lost unless grown within natural forest settings. In response, TBGRI organized 50 Kani families living inside the forest to cultivate the plant under the supervision of the scientists. This was also touted as a creative employment-generation program; each Kani family would manage the semiwild crop, cultivating one or two acres and earning about Rs. 30,000 (or \$715) per acre, with the yield and production of leaves expected to increase in subsequent years for an anticipated 20 to 30 years. Because the Kani are essentially forest dwellers, they were assumed to be in an effective bargaining 
position to regulate and control its harvest. But then an unexpected player entered the conversation: the state forest department, which officially controls and regulates the forest area. Although it had contributed no material or finances to the research effort, the forest department demanded a share of the license fee and royalties on the grounds that the plant material collected is endemic to the forest. The TBGRI was forced to renegotiate the terms of the agreement to include the forest department, all of which further cut back into the profit share received by the Kanis.

The main outcome was that even though the original benefit-sharing agreement fell apart, the drug manufacture continued as planned. In other words, this state-sponsored heritage compensation scheme, which relied on tribal medical knowledge without consent from the Kanis, did not ultimately disturb the market production and circulation of this Ayurvedic drug to national and even international markets. Thus, the payments continued to be made into the Trust, but from all accounts, the Trust itself lost any legitimacy to distribute the funds to its constituents. The Kani now seem to want to choose their own future vis-à-vis their medical heritage. Eight years after the benefit-sharing agreement was signed, the manufacturing license expired in August 2006. Fueled by NGO critiques that the benefit-sharing arrangement by TBGRI essentially traded and privatized the common heritage of humanity, Kani pancayat leaders are now aware that they could have denied both access and consent to TBGRI researchers. In a fitting end to the story, Kani pancayat leaders - along with a representative group of all the tribal healers, or Plathis - have announced that they will not renew the license with Arya Vaidya Pharmacy. ${ }^{68}$ Instead, they have announced plans to float a factory themselves with the combined help of all three pancayat bodies, instead of privatizing their medical knowledge to cultural outsiders whose drug manufacture stands to make a profit from their heritage.

The postscript to this story is almost apocryphal. Through the entire decade of research and organization, neither TBGRI nor any other agency of the government thought to secure an international trademark or a product patent that could be valid in international markets. In the interim, a leading U.S. food supplement manufacturer and vitamin store chain, the Great Earth Companies, Inc., managed to seize the opportunity and secure trademark rights for Jeevani (the name under which it had first been marketed in India). Great Earth Companies now uses Jeevani in its widely marketed product Jeevani Jolt 1000 without technically infringing on the IPRs of the original drug. ${ }^{69}$ This perhaps is the ultimate irony. After eight years of research that relied on Kani tribal knowledge, and a benefit-sharing arrangement that was touted as a model compensation scheme to "give back" equitable returns to the South, Jeevani is now available in the west as an energizer, antistress adaptogen, and immune system supporter for a mere $\$ 21.99$ for 60 capsules. TMK and medical heritage, it seems, can always be discovered, commodified, and owned far from its place of origin. 


\section{CODA: WHO OWNS AYURVEDA?}

In the end, what big picture can we describe that emerges from these several smaller narratives, this mosaic, of Ayurvedic heritage disputes? How do we begin to sort through this diversity of cultural ownership practices to come up with overarching theories about Ayurvedic knowledge, let alone TMK, or intangible cultural heritage? And who really owns TMK? Is it owned by indigenous groups like the Ezhavas who have been left out of history? Is it owned by elite practitioners who claim exclusive rights of use over Ayurvedic texts? Is it owned by tribals, who provided the medical knowledge in the first place, or the Ayurvedic company that bought the license for those rights? Or is it owned by the forest as the ultimate public domain? If nothing else, these three contrasting tales of cultural ownership over the same medical tradition suggest that even the questions asked by state-based heritage protection schemes can differ widely. Thus, the Hortus Malabaricus case asks whether TMK is owned by history or if it can be rewritten-that is, whether the past itself is a scarce resource, as anthropologists have begun to formulate. ${ }^{70}$ The TKDL case asks whether traditional knowledge (encoded in texts) should be part of the public domain or not, and whether such textual knowledge can be exclusively owned by a nation or even an elite professional group. The Kani case assumes that TMK is collectively owned but asks how these communities should be defined or compensated for their heritage.

The larger problem is that if, even within a single medical tradition, heritage protection schemes do not always share similar definitions of what heritage is or who it is supposed to protect, where does one even begin to theorize ownership of TMK or intangible heritage? At the risk of simplifying, perhaps one beginning lies in recognizing the dialectical relationship between culture (or heritage) and the law: that in this case, even if culture needs the law to regulate and protect it, the law in turn, however well intentioned and necessary, produces culture, produces knowledge, and thus produces further claims and counterclaims of ownership over TMK. As has already been suggested, making heritage legible is a double-edged sword: it transforms cultural objects and marginalizes cultural producers, but it also creates new types, categories, and subjectivities to be managed and controlled.

This is not to say that heritage and TMK regulation is unnecessary or even Orwellian in nature. It is merely to note that there may never be universal answers to global heritage disputes. Real-life solutions to heritage crises may in fact emerge slowly, on a case-by-case basis. State practices might inspire indigenous responses and both of them might work with and against the logic of the market; but the most creative, innovative solutions often come from civil society-professionals, NGO advocacy groups, educational institutions, libraries, archives, curators-all of whom, as we know from NAGPRA legislation in the United States, are the ones building the cultural policy edifice slowly, brick by brick. 
Nor am I arguing that the effects of cultural ownership over TMK are all negative. The Law of Unintended Consequences in heritage protection after all is precisely that: unintended. Some authors have suggested that even with new indigenous rights legislation in place, disempowered groups are unlikely to benefit much from new laws because powerful interests are simply better positioned to use or evade them. ${ }^{71}$

Nonetheless, even if indigenous cultural claims mimic the propertization discourse to turn heritage into a resource to be owned (the commoditization of culture that critics bemoan), they also reveal that propertization itself could, if used well, have emancipatory potential. As these disputes over Ayurvedic knowledge show, indigenous groups can use property, particularly IP, to make themselves subjects and not just objects in the law. Legal scholars have noted that these could well be the new social movements and the new cultural heritage citizens of the twenty-first century. Although it remains to be seen how ownership claims eventually play out, this property turn in cultural identity politics could ultimately be transformative. It could, in fact, lead to a real politics of redistribution, to a redistributive justice between groups that goes well beyond the sterile politics of recognition that has dominated cultural heritage disputes in the past.

\section{ENDNOTES}

1. Scott, Seeing Like a State, 2-3. In Scott's thesis state practices are the perennial efforts to take complex, illegible, mobile, and local social practices and render them legible in the service of classic state functions of taxation, conscription, and prevention of rebellion. Scott claims that these schemes are perennial in part because they rarely succeed and are in fact often disasters waiting to unfold.

2. Convention on Biological Diversity (CBD), 1992.

3. Convention for the Safeguarding of the Intangible Cultural Heritage (CSICH), 2003.

4. Article 2, Section 3 of the $2003 \mathrm{CSICH}$, which calls for a range of measures "aimed at ensuring the viability of the intangible cultural heritage including the identification, documentation, research, preservation, protection, enhancement, transmission, particularly through formal and nonformal education, as well as the revitalization of various aspects of such heritage."

5. See Brown, Heritage Trouble, for an excellent recent review of heritage practice and intangible cultural heritage debates; Hayden, When Nature Goes Public, for an analysis of the making of bioprospecting schemes; and Greene, Indigenous Knowledge, Incorporated. for a review of privatizing indigenous knowledge.

6. I am grateful to an anonymous reviewer for this last point.

7. For a recent articulation of cosmopolitan ownership, see Appiah, Cosmopolitanism, 115. See Strathern, Property, Substance and Effect, 167, for a superb discussion on how IPRs re-embed and recontextualize traditional knowledge and culture.

8. See Safrin, "Hyperownership in a Time of Technological Promise"; Chander and Sunder, "The Romance of the Public Domain"; and Leach, "Owning Creativity."

9. For good overviews of biological or genetic citizenship outside the context of TMK, see Rose and Novas, Biological Citizenship; Petryna, Life Exposed; or Rapp, et al., "Genetic Citizenship."

10. Das and Poole, Anthropology in the Margins of the State, offers an excellent exposition of this argument. The volume also describes how it is precisely the illegibility of the state that makes the double aspect of rationality and magicality the defining feature of the state in its margins. For the latter argument, see also Taussig, The Magic of the State. 
11. Foucault, Discipline and Punish, in which he distinguishes between sovereign and disciplinary power in surveillance techniques. See also his notion of biopower that he begins to lay out in Birth of the Clinic.

12. See Zimmermann, Jungle and the Aroma of Meats; and Wujastyk, The Roots of Ayurveda, for more on classical Ayurveda, which relies on humoral diagnostics and a therapeutic armamentarium that involves a combination of internal medicine (kayachikitsa), herbal remedies (dravyaguna), and rejuvenation programs (rasayana). See Leslie and Young, Paths to Asian Medical Knowledge; and Langford, Fluent Bodies, for more on contemporary Ayurvedic practice, which in South Asia reflects a long history of professionalizing reform of this medical tradition as part of a larger nationalist project of indigenous revival. See also Reddy, Reinventing Medical Traditions, and "Asian Medicine in America," for more recent transformations of Ayurveda in the United States. For more on the nationalist project and its effects on the cultural sphere, see Chatterjee, The Nation and its Fragments.

13. Don Bates, ed. Knowledge and the Scholarly Medical Traditions.

14. Brown, "Can Culture Be Copyrighted?," 193-222.

15. Deborah Root, Cannibal Culture, offers an early analysis of the escalation of moral panic with biocolonialism.

16. Brown "Heritage Trouble."

17. Brown, "Heritage Trouble"; Sunder, "Intellectual Property and Identity Politics" and "Cultural Dissent"; Coombe, The Cultural Life of Intellectual Properties; and Cowen, Creative Destruction.

18. See for example, Brown, "Heritage Trouble," 46; Barsh, How do you Patent a Landscape?; and Posey and Dutfield, Beyond Intellectual Property. For a more general description of the same process with indigenous knowledge, see Agrawal, "Indigenous Knowledge and the Politics of Classification."

19. Parry, Trading the Genome, 24.

20. Marilyn Strathern, Property, Substance and Effect.

21. Reddy, Reinventing Medical Traditions, Chapter 7.

22. For comprehensive histories of Ayurveda's professionalization, see Leslie and Young, Paths to Asian Medical Knowledge; Leslie, Asian Medical Systems; Bala, Imperialism and Medicine; and Langford, Fluent Bodies. For a longer history of Ayurveda's heterodox origins, see Zimmermann, The Jungle and the Aroma of Meats; Zysk, Asceticism and Medicine; and Wujastyk, The Roots of Ayurveda.

23. Appadurai, Modernity at Large, 6.

24. Merryman, "Two Ways of Thinking about Cultural Property," 836.

25. Scott, Seeing Like a State, 31-32.

26. For a good overview, see Mitchell, The Rule of Experts. For the process of cultural production through colonialism in South Asia, see Dirks, Castes of Mind.

27. CSICH, 2003.

28. Watkins, "Cultural Nationalists, Internationalists and 'Intra-nationalists"” For an overview of enclosures in the public domain, see Boyle, “The Second Enclosure Movement." For a description of how enclosures exploit traditional knowledge, see Shiva et al., "The Enclosure and Recovery of the Commons."

29. The shift in global cultural disputes from the protracted dispute over stolen bronze icons in the 1980s is described in Davis, Lives of Indian Images; and Weil, "Who Owns the Nataraja?" The more recent Neem campaign and the turmeric wars is described in Shiva, "The Neem Campaign."

30. For a general description of Ayurveda's twentieth-century professionalizing failures based on practice, see Leslie and Young, Paths to Asian Medical Knowledge. See also Langford, Fluent Bodies, for the recent shift to national disputes over Ayurvedic knowledge.

31. Benjamin, "The Work of Art in the Age of Mechanical Reproduction," 221.

32. Brown, "Heritage Trouble"; Chander and Sunder, "Romance of the Public Domain."

33. See Lessig, Free Culture; and Boyle, Shamans, Software and Spleens, for early expositions of this argument.

34. Hayden, When Nature Goes Public.

35. Chander and Sunder, "Romance of the Public Domain," 1335.

36. For a good historical introduction to Van Rheede and his text, see Heniger, Hendrik Adriaan van Rheede tot. 
37. For a description of the dominance of low-caste epistemologies in Portuguese botanical texts, see Boxer, "Two Pioneers of Tropical Medicine." See also Grove, Green Imperialism, Chapter 8; and Grove, "Indigenous Knowledge and the Significance of South-West India."

38. Ranjit Devraj, "325-Year-Old Dutch Work on Kerala's Plant Wealth Revived," Asia Times Online, May 8, 2003 〈http://www.indiasocial.org〉 accessed September 19, 2006; see also Mohan Ram, "On the English Edition of Van Rheede."

39. For earlier versions of this argument, see also Manilal, Botany and History of Hortus Malabaricus; Fournier, "The Hortus Malabaricus of Hendrik van Rheede tot Drakenstein”; and Heniger, Hendrik Adriaan Van Rheede.

40. See Mohan Ram, "On the English Edition of Van Rheede's Hortus Malabaricus."

41. Jayaraman, "Biopiracy Fears Cloud Indian Database," December 5, 2002, 〈http://www.scidev.net〉 accessed September 24, 2006.

42. See for example, The Economist, "Finding drugs in the library," September 5, 2004.

43. UN Draft Declaration on the Rights of Indigenous Peoples, 1993, 〈http://www.iwgia.org/ sw248.asp $\rangle$ accessed September 23, 2006.

44. See Suvarna Kumar, Deccan Herald, 2004. For more on Ezhava political claims, see also Srinivasan, "The Year of Sree Narayana Guru," August 30, 2004 〈http:www.rediff.com〉 accessed September 24, 2006; and Cherian, Perspectives on Kerala History 〈http://www.keralahistory.ac.in/ casteandsocial.htm $\rangle$ accessed September 24, 2006.

45. Watkins, "Cultural Nationalists." For similar views on cultural rights, see Robbins and Stamatopoulou, "Reflections on Culture and Cultural Rights."

46. Shiva, The Neem Campaign, 4; for more on the Neem Campaign, see Third World Network, A Case of Biopiracy 〈http://www.twnside.org.sg/title/pir-ch.htm〉 accessed September 24, 2006.

47. Convention to Safeguard the Intangible Cultural Heritage, 2003, Article 12, section 1.

48. Chander and Sunder, "Romance of the Public Domain," 1358.

49. Dirks, Castes of Mind, provides a good historical overview of archive creation in nineteenthcentury India.

50. See Chander and Sunder, "Romance of the Public Domain," 1357-1358; Mashelkar, "Intellectual Property Rights and the Third World," 12.

51. Mashelkar, The Story of the TKDL, 16.

52. Padma, T.V. "Digital Library to Protect Indigenous Knowledge," January 10, 2005, Science and Development Network 〈http://www.scidev.net〉 accessed September 15, 2006.

53. See WIPO, Report on Intellectual Property and Traditional Knowledge, 〈http://www.wipo.int/ freepublications/en/tk/wipo_pub_920.pdf) accessed September 24, 2006.

54. See Harrison, "Community Biodiversity Registers"; Utkarsh, "Documentation of Traditional Knowledge"; Downes and Laird, "Community Registers of Biodiversity-Related Knowledge."

55. SARAI's conference on digital technology information and traditions explored many of these issues.

56. For a history of this professionalizing schism, see for instance, Leslie, Asian Medical Systems; Leslie and Young, Paths to Asian Medical Knowledge; and Brass, "The Politics of Ayurvedic Education."

57. Some of this history is recounted in Shiv Sharma's Ayurvedic Medicine; see also Leslie in Paths to Asian Medical Knowledge, 177-208, for a biographical history of leading Ayurvedic advocates.

58. See Report of AYUSH, goverment of India, 2003, 〈http://www.indianmedicine.nic.in html/ ismh/annual/annual.htm $\rangle$ accessed September 24, 2006.

59. See Brown, "Heritage Troubles" or "Can Culture be Copy-righted?" for a description of this process.

60. Report of the Department of Ayurveda, Yoga, Unani, Siddha and Homeopathy, on Ayurveda, New Delhi, 2004.

61. Letter to the editor, Indian Express, September 4, 2004.

62. See text of speech at the Government Center for Ayurvedic, Siddha and Homeopathic Medicine, 2003. For descriptions of the two court cases, see Weil, "Who Owns the Nataraja"; and Davis, Lives of Indian Images; see also Reddy, "The Memory of Divine Objects." 
63. Reddy, "The Politics and Poetics of Magazine Medicine."

64. CBD, 1992, Article 2.

65. See Hayden, When Nature Goes Public, for an excellent ethnography of benefit-sharing. See also Hayden's "Benefit-sharing" for an overview of benefit-sharing agreements in relation to IP law.

66. See Gupta, "Value-Addition to Local Kani Tribe Knowledge," for an in-depth account and evaluation of the benefit-sharing scheme with the Kani tribe.

67. The Indian Constitution, $73^{\text {rd }}$ Amendment Act, 1992. For more information, see the Goverment of India Ministry of Pancayat Raj's National Pancayati Portal, 〈http://panchayat.nic.in〉accessed September 24, 2006.

68. Report of the Tropical Botanic Garden Research Institute, 2005.

69. See G. Rajiv, "U.S. Firm Patents Kerala Tribe's Jeevani," January 6, 2006, 〈http:// www.indiamonitor.com $\rangle$ accessed July 15, 2006.

70. For other work on the past as heritage resource, see Appadurai, "The Past as a Scarce Resource," for an early articulation of the argument; see also Harrison, "Identity as a Scarce Resource." For the past as cultural and intellectual properties, see Nicholas and Bannister, "Copyrighting the Past?"

71. See for example Michael Davis, "Some Realism About Indigenism."

\section{BIBLIOGRAPHY}

Agrawal, Arun. "Indigenous Knowledge and the Politics of Classification." International Social Science Journal 54 (2002): 173, 287-297

Aoki, Keith. "Intellectual property and sovereignty: Notes toward a cultural geography of authorship." Stanford Law Review 48 (1996) no. 5: 1293-1355.

Appadurai, Arjun. Modernity at Large: Cultural Dimensions of Globalization. Delhi: Oxford University Press, 1996.

_. "The Past as Scarce Resource." Man, N.S. 16 (1981): 201-219.

Appiah, Kwame Anthony. Cosmpolitanism: Ethics in a World of Strangers. New York: W. W. Norton, 2006.

Bala, Poonam. Imperialism and Medicine in Bengal: A Soci-Historical Perspective. New Delhi: Sage Publications, 1991.

Bannister, Kelly, and Katherine Barrett. "Challenging the Status Quo in Ethnobotany: A New Paradigm for Publication May Protect Cultural Knowledge and Traditional Resource." Cultural Survival Quarterly 24, no. 4 (2001): 10-13.

Barsh, Russel L. "How Do You Patent a Landscape? The Perils of Dichotomizing Cultural and Intellectual Property." International Journal of Cultural Property 8, no. 1 (1990): 14-47.

Bates, Don, ed. Knowledge and the Scholarly Medical Traditions. Cambridge: Cambridge University Press, 1995.

Benjamin, Walter. "The work of Art in the Age of Mechanical Reproduction." in Illuminations, 217251. New York. Schocken Books, 1969.

Boxer, C.R. “Two Pioneers of Tropical Medicine: Garcia d'Orta and Nicolas Monardes.” Diamante 1963, XIV, 133.

Boyle, James. Shamans, Software, and Spleens: Law and the Construction of The Information Society. Cambridge: Harvard University Press, 1999. 
- "The Second Enclosure Movement and the Construction of the Public Domain." Law \& Contemporary Problems 66 (2003): 33.

Branscomb, Anne Wells. Who Owns Information? From Privacy to Public Access. New York: Basic Books, 1996.

Brass, Paul. "The Politics of Ayurvedic Education: A Case Study of Revivalism and Modernization in India” In Education and Politics in India, edited by S. H. Rudolph and L. I. Rudolph, 342-371. Cambridge, MA: Harvard University Press, 1972.

Brown, Michael. F. “Can Culture Be Copyrighted?” Current Anthropology 39, no. 2 (1998): 193-222.

Brown, Michael F. Who Owns Native Culture? Cambridge: Harvard University Press, 2003.

- "Heritage Trouble: Recent Work on the Protection of Intangible Cultural Property." International Journal of Cultural Property, 12, no. 1 (February 2005): 40-61.

. "Heritage as Property." In Property in Question: Value Transformation in the Global Economy, edited by Katherine Verdery and Caroline Humphrey, 49-68. Oxford: Berg, 2004.

Brush, Stephen B. “Is Common Heritage Outmoded?” In Valuing Local Knowledge: Indigenous People and Intellectual Property Rights, edited by Stephen Brush and Doreen Stabinsky, 143-164. Washington, DC: Island Press, 1996.

Chander, Anupam, and Madhavi Sunder. "The Romance of the Public Domain." California Law Review 92 (2004): 1331-1374.

Chatterjee, Partha. The Nation and Its Fragments: Colonial and Postcolonial Histories. Princeton, NJ: Princeton University Press, 1993.

Clifford, James. The Predicament of Culture: Twentieth-Century Ethnography, Literature, and Art. Cambridge: Harvard University Press, 1988.

Coombe, Rosemary J. The Cultural Life of Intellectual Properties: Authorship, Appropriation, and the Law. Durham: Duke University Press, 1998.

Cowen, Tyler. Creative Destruction: How Globalization is Changing the World's Cultures. Princeton, NJ: Princeton University Press, 2002.

Das, Veena. "Cultural Rights and the Definition of Community," In The Rights of Subordinated Peoples, edited by Oliver Mendelsohn and Upendra Baxi, 117-158. Delhi: Oxford University Press, 1994.

Das, Veena, and Deborah Poole, eds. Anthropology in the Margins of the State: Comparative Ethnographies. New Delhi: Oxford University Press, 2004.

Dasgupta, Kaushik. “The Garden of Malabar: A Biopiracy Story." Down to Earth, Science and Environment Online, March 22, 2005 〈http://www.downtoearth.org〉 accessed September 15, 2006.

Davis, Michael. "Some Realism About Indigenism." Cardozo Journal of International and Comparative Law 11 (Summer 2003): 815-830.

Davis, Richard. Lives of Indian Images. Princeton, NJ: Princeton University Press, 1999.

Dirks, Nicholas. Castes Of Mind: Colonialism and the Making of Modern India. Princeton, NJ: Princeton University Press, 2001.

Downes, David. R., and Sarah A. Laird. "Community Registries of Biodiversity-Related Knowledge The Role of Intellectual Property in Managing Access and Benefit,” UNCTAD Biotrade Initiative, 1999.

Dutfield, Graham. The Public and Private Domains: Intellectual Property Rights in Traditional Knowledge. Science Communication 21 (2000): 274-295. 
The Economist, "Finding Drugs in the Library: Researchers Are Searching for New Medicines Lurking in Old Herbal Texts," September 25, 2004.

Foucault, Michel. Birth of the Clinic: An Archeology of Medical Perception. New York: Vintage, 1975.

Foucault, Michel. Discipline and Punish. New York: Vintage Books, 1980.

Fournier, M. “The Hortus Malabaricus of Hendrik van Rheede tot Drakenstein." In Botany and History of Hortus Malabaricus, edited by K.S. Manilal. New Delhi: Oxford and IBH Publishing Co., 1980.

Greene, Shane. “Indigenous Knowledge, Incorporated." Current Anthropology 45, no. 2 (April 2004): 211-237.

Grove, Richard. Green Imperialism. Cambridge: Cambridge University Press, 1995.

"Indigenous Knowledge and the Significance of South-West India for Portuguese and Dutch Constructions of Tropical Nature." Modern Asian Studies 30, no. 1 (February 1996), 121-143.

Gupta, Anil K. Value Addition to Local Kani Tribal Knowledge: Patenting, Licensing and BenefitSharing. Report for the World Intellectual Property Organization, 2002.

Harrison, Kate. "Community Biodiversity Registers as a Mechanism for the Protection of Indigenous and Local Knowledge." Sustainable Use of Biodiversity Program Initiative, International Development Research Centre, Canada, 2000.

Harrison, Simon. “Identity as a Scarce Resource." Social Anthropology 7, no. 3 (1999): 239-251.

Hayden, Corinne. "Benefit-Sharing: Experiments in Governance." Paper presented at the SSRC Workshop on Intellectual Property, Markets and Cultural Flows, New York, October 24-25, 2003.

. When Nature Goes Public: The Making and Unmaking of Bioprospecting in Mexico. Princeton, NJ: Princeton University Press, 2005.

Heniger, J. Hendrik Adriaan Van Rheede tot Drakenstein and Hortus Malabaricus: A Contribution to the Study of Dutch and Colonial Botany. Boston: A. A. Balkema, 1986.

Langford, Jean M. Fluent Bodies: Ayurvedic Remedies for Postcolonial Imbalance. Durham, NC: Duke University Press, 2002.

Leach, James. "Owning Creativity: Cultural Property and the Efficacy of Custom on the Rai Coast of Papua New Guinea." Journal of Material Culture 8, no. 2 (2003): 123-144.

Leslie, Charles M., ed. Asian Medical Systems: A Comparative Study. Berkeley: University of California Press, 1976.

Leslie, Charles, and Allan Young, eds. Paths to Asian Medical Knowledge. Berkeley: University of California Press, 1992.

Lessig, Lawrence. Free Culture: How Big Media Uses Technology and the Law to Lock Down Culture and Control Creativity. New York: Penguin, 2004.

Manilal, K.S., ed. Botany and History of Hortus Malabaricus. New Delhi: Oxford and India Book House, 1980.

- "The epigraphy of the Malayalam certificates in Hortus Malabaricus." In Botany and History of Hortus Malabaricus, edited by K.S. Manilal, 113-120, 1989.

Manilal, K.S., C.R. Suresh, and V.V. Sivarajan. "A Reinvestigation of the Plants Described in Rheede's Hortus Malabaricus: An Introductory Report.” Taxon 26 (1977): 549-550.

Mashelkar, Raghunath A. Report on Intellectual Property Rights and the Third World 12. 〈http:// sustsci.harvard.edu/ists/TWAS_0202/mashelkar_undated.pdf $\rangle$ accessed September 15, 2006. 
Merryman, John Henry. “Two Ways of Thinking About Cultural Property.” American Journal of International Law 80 (1986): 831-835.

—. "Cultural Property Internationalism." International Journal for Cultural Property, 12, no. 1, (February 2005).

Mohan Ram, H.Y. “On the English Edition of Hortus Malabaricus by K.S. Manilal (2005)." Current Science 89, no. 10 (2005): 1672-1680.

Mitchell, Timothy. Rule of Experts: Egypt, Techno-Politics, Modernity. Berkeley: The University of California Press, 2002.

Nicholas, George P. and Kelly P. Bannister. "Copyrighting the Past? Emerging Intellectual Property Rights Issues in Archeology.” Current Anthropology 45, no. 3 (2004): 327-350.

Parry, Bronwyn. Trading the Genome: Investigating the Commodification of Bio-Information. New York: Columbia University Press, 2004.

Petryna, Adriana. Life Exposed: Biological Citizens after Chernobyl. Princeton, NJ: Princeton University Press, 2003.

Posey, Darrell A., and Graham Dutfield. Beyond Intellectual Property: Toward Traditional Resource Rights for Indigenous Peoples and Local Communities. Ottawa: International Development Research Centre, 1996.

Rapp, Rayna, Deborah Heath, and Karen-Sue Taussig. "Genetic Citizenship." In Companion to the Handbook of Political Anthropology, edited by David Nugent and Joan Vincent. Oxford: Blackwell, 2003.

Reddy, Sita. Reinventing Medical Traditions: The Professionalization of Ayurveda in America. Unpublished dissertation, University of Pennsylvania, 2000.

- “The Politics and Poetics of Magazine Medicine." In Robert Johnston, ed. Politics of Healing: A History of Alternative Medicine in Twentieth-Century North America, Routledge, 2003.

. "Asian Medicine in America: The Ayurvedic Case." Annals of the American Academy of Political and Social Science 583 (2002): 97-121.

- "The Memory of Divine Objects: Remembrance and Repatriation" (For the Smithsonian Material Culture Forum on The Remembrance of Things, How Museums and Memory Shape One Another, held September 2005). Material Matters 54 (June 2006): 10-12.

Report of the Department of the Ayurveda, Yoga \& Naturopathy, Unani, Siddha and Homeopathy (AYUSH), Ministry of Health and Family Welfare, Government of India, 2003.

Robbins, Bruce, and Elsa Stamatopoulou. "Reflections on Culture and Cultural Rights." South Atlantic Quarterly 103, no. 2/3 (2004): 227-259.

Root, Deborah. Cannibal Culture: Art, Appropriation and the Commodification of Difference. Boulder, Colorado: Westview Press, 1995.

Rose, Nikolas, and Carlos Novas, "Biological Citizenship." In Global Assemblages: Technology, Politics, and Ethics as Anthropological Problems, edited by Aihwa Ong and Stephen J. Collier, 439-463. Oxford: Blackwell, 2005.

Sarai Reader 01: The Public Domain. New Delhi and Amsterdam: Sarai Media Collective, 2001.

Safrin, Sabrina. "Hyperownership in a Time of Biotechnological Promise: The International Conflict to Control the Building Blocks of Life." American Journal of International Law, 98, no. 4 (2004): $641-685$. 
Scott, James. Seeing Like a State: How Certain Schemes to Improve the Human Condition Have Failed. New Haven: Yale University Press, 1998.

Shiv Sharma, Pandit. Ayurvedic Medicine: Past and Present. Varanasi: Krishnadas Academy.

Shiva, Vandana et al. The Enclosure and Recovery of the Commons: Biodiversity, Indigenous Knowledge and Intellectual Property Rights, 1997.

—. "The Neem Campaign.” Dehradun: Research Foundation for Science and Technology \& Natural Resource Policy, 1993.

Strathern, Marilyn. Property, Substance and Effect: Anthropological Essays on Persons and Things. London: Athlone Press, 1999.

. "Multiple Perspectives on Intellectual Property." In Protection of Intellectual, Biological and Cultural Property in Papua New Guinea, edited by Kathy Whimp and Mark Busse, 47-61. Canberra: Asia Pacific Press, 2000.

Sunder, Madhavi. "Intellectual Property and Identity Politics: Playing with Fire" Journal of Gender, Race and Justice 4, no. 1 (2000), 69-98.

—. "Cultural Dissent." Stanford Law Review 54, no. 3 (2001): 495-567.

Taussig, Michael. The Magic of the State. New York: Routledge, 1997.

United Nations Convention on Biological Diversity. Rio de Janeiro: UNEP, 1992.

United Nations Educational, Scientific and Cultural Organization. Convention for the Safeguarding of the Intangible Cultural Heritage. Paris: UNESCO, 2003.

Utkarsh, G. “Documentation of Traditional Knowledge: People's Biodiversity Registers.” Report for the Foundation for Revitalisation of Local Health Traditions. Bangalore: FRLHT, 2002.

Watkins, Joe. "Cultural Nationalists, Internationalists and 'Intra-nationalists': Who's Right and Whose Right?” International Journal of Cultural Property, 12, no. 1 (February 2005): 78-94.

Weil, Stephen. "Who Owns the Nataraja?” Art News, 5 (1989), 188.

Wujastyk, Dominik. The Roots of Ayurveda. New Delhi: India Penguin, 1988.

Zimmerman, Francis. The Jungle and the Aroma of Meats: An Ecological Theme in Hindu Medicine. Berkeley: University of California Press, 1987.

Zysk, Kenneth. Asceticism and Healing in Ancient India: Medicine in the Buddhist Monastery. Oxford: Oxford University Press, 1991. 